\title{
miR-21-5p ameliorates hyperoxic acute lung injury and decreases apoptosis of AEC II cells via PTEN/AKT signaling in rats
}

\author{
SONG QIN, HONGLIANG WANG, GUOYUE LIU, HONG MEI and MIAO CHEN \\ Intensive Care Unit, Affiliated Hospital of Zunyi Medical University, Zunyi, Guizhou 563000, P.R. China
}

Received July 4, 2019; Accepted October 4, 2019

DOI: $10.3892 / \mathrm{mmr} .2019 .10779$

\begin{abstract}
Inhibiting apoptosis of type II alveolar epithelial cells (AEC II) is an effective way to decrease hyperoxic acute lung injury (HALI); however, the specific underlying molecular mechanisms have not yet been fully elucidated. Although miRNA-21-5p has previously been reported to decrease $\mathrm{H}_{2} \mathrm{O}_{2}$-induced AEC II apoptosis by targeting PTEN in vitro, whether miR-21-5p can decrease HALI in vivo and the downstream molecular mechanisms remain unclear. In the present study, rats were endotracheally administered with an miR-21-5p-encoding (AAV-6-miR-21-5p) or a negative control adenovirus vector, and then a HALI model was established by exposure to hyperoxia. At 3 weeks following the administration of AAV-6-miR-21-5p, the severity of HALI was decreased, as evidenced by the improved outcome of the oxygenation index, respiratory index, wet/dry weight ratio and pathological scores of the HALI lungs. To further investigate the underlying mechanisms, AEC II cells were isolated from the lungs of the experimental rats and cultured. The expression levels of miR-21-5p and its target gene, PTEN, were detected, as well as the levels of phosphorylated and total AKT. In addition, the apoptosis rate of AEC II was detected by flow cytometry. The results demonstrated that AAV-6-miR-21-5p administration increased the miR-21-5p levels in primary AEC II cells, while it decreased the expression levels of PTEN. miR-21-5p overexpression also increased AKT phosphorylation in AEC II cells from the HALI lungs compared with that of the HALI alone group and the control virus group. The present study indicated that miR-21-5p ameliorated HALI in vivo, which may have resulted from the inhibition of PTEN/AKT-induced apoptosis of AEC II cells. These findings suggest that miR-21-5p and PTEN/AKT signaling might serve as potential targets for HALI treatment.
\end{abstract}

Correspondence to: Dr Miao Chen, Intensive Care Unit, Affiliated Hospital of Zunyi Medical University, 149 Dalian Road, Zunyi, Guizhou 563000, P.R. China

E-mail: chenmiaoicu@163.com

Key words: hyperoxic acute lung injury, microRNA, apoptosis, miR-21-5p, PTEN, AKT

\section{Introduction}

Hyperoxia-induced acute lung injury (HALI) is a typical complication of oxygen therapy, and can result in acute respiratory distress syndrome (ARDS) (1). In HALI, the hyperoxia can cause apoptosis and necrosis of alveolar epithelial cells (AEC) (2). In addition, apoptosis was associated with hyperoxia toxicity, lung injury and a decrease in survival rate in rats (3). Type II AEC (AEC II) is the cell origin of AEC. AEC II are essential for maintaining homeostatic pulmonary function under normal physiological conditions. Hyperoxia, however, results in loss of epithelial integrity in AEC II, by increasing apoptosis and possibly by enhancing epithelial transdifferentiation $(4,5)$. Loss of AEC integrity then contributes to cytokine release and enhanced immune cell recruitment under HALI conditions (6). HALI (7), ARDS (8), pulmonary fibrosis (9) and other oxidative stress-related lung diseases are the predominant reasons for AEC-II apoptosis. AEC II are the primary target cells of high oxygen $(4,7)$, and AEC II apoptosis is considered to be the underlying mechanism for the pathogenesis of HALI $(10,11)$. The survival or apoptosis of AEC II directly affect the degree of lung injury and repair. For example, transforming growth factor- $\beta$ receptor interacting protein- 1 can reduce AEC apoptosis and increase the resistance to HALI (2). It has previously been reported that inhibiting apoptosis of AEC II effectively decreased HALI in rats (12). Therefore, AEC II apoptosis is a key contributor of HALI, inhibition of which may be an effective way to decrease the incidence of HALI, and ultimately provide a cure.

MicroRNAs (miRNAs) are a type of small non-coding RNAs of 18-22 nucleotides that are widely expressed in tissues and organs throughout the body. miRNAs are involved in cell growth, proliferation, differentiation, apoptosis, metabolism and other biological processes. miRNA-21 has been reported to be associated with multiple pathological conditions, including tumor development $(13,14)$, cardiovascular (15-17), liver (18), lung $(19,20)$ and renal $(21)$ diseases, as well as diabetes $(22)$. Using microarray methods, it was revealed that miR-21-5p was differentially expressed in AEC II cells during hyperoxia, and in specific in the $\mathrm{H}_{2} \mathrm{O}_{2}$-induced HALI model (23). miR-21-5p overexpression in AEC II significantly decreased apoptosis $(23,24)$, which may be attributed to inhibition of its target gene PTEN (24). miR-21-5p overexpression in the HALI lung effectively decreased HALI severity in rats $(23,25)$. These results suggest that miR-21-5p could alleviate AEC II apoptosis 
in HALI and decrease lung damage, but its anti-apoptotic mechanisms are not yet fully understood.

Previous studies $(24,26)$ have suggested that PTEN is one of the target genes of miR-21-5p. PTEN/AKT signaling has been reported to inhibit cell cycle progression, and promote apoptosis $(27,28)$. In addition, it has been widely reported that miR-21 reduces apoptosis by targeting PTEN and inhibiting PTEN/AKT signaling $(17,29)$. The present study investigated the association between miR-21-5p, PTEN, AKT and AEC II apoptosis, and speculated that miR-21-5p may decrease AEC II apoptosis via PTEN and AKT-associated mechanisms.

\section{Materials and methods}

Materials. AAV-6-miR-21-5p-GFP [miR-21-5p mimic (UGU CGGGUAGCUUAUCAGACUGAUGUUGACUGUUGAAUC UCAUGGCAACACCAGUCGAUGGGCUGUCUGACA) and green fluorescent protein (GP) encoded in an adeno-associated virus (AAV) type 6 vector] and AAV-6-miR-21-5p negative control (only GFP encoded in the AAV-6 vector) were from Synthgene Biotechnology Co., Ltd. Primers used for reverse transcription-quantitative PCR (RT-qPCR) experiments were from Thermo Fisher Scientific, Inc. Fetal bovine serum (FBS), DMEM/F12 and DMEM-low glucose medium (Gibco; Thermo Fisher Scientific, Inc.), Annexin V-FITC/propidium iodide (PI) cell apoptosis detection kit (BD Biosciences), QuantiTect SYBR Green PCR kit (Takara Bio, Inc.), HiScript ${ }^{\circledR}$ II 1st Strand cDNA Synthesis kit (Vazyme), bicinchoninic acid (BCA) protein quantification kit and SDS-PAGE gel preparation kit (Beyotime Institute of Biotechnology) were utilized in the present study. Antibodies targeting PTEN (cat. no. ab32199), AKT (cat. no. ab8805), phosphorylated (p) AKT (cat. no. ab38449), and GAPDH (cat. no. ab181602), and the secondary horseradish peroxidase (HRP)-labeled antibody, were from Abcam. The unlisted reagents were of analytical grade.

Instruments. The present study utilized a FACSCalibur flow cytometer (BD Biosciences), an inverted fluorescence microscope (Nikon Corporation), a light microscope (Leica Microsystems $\mathrm{GmbH}$ ), a fluorescence quantitative PCR instrument (Bio-Rad Laboratories, Inc.), a full-wavelength fluorescent microplate reader (Thermo Fisher Scientific, Inc.) and a transmission electron microscope (TEM; Hitachi, Ltd.).

Animals and grouping. All experimental procedures were performed according to the 'Guide for the Care and Use of Laboratory Animals' in China, and approved by the Experimental Animal Care and Use Committee of Zunyi Medical University. Sprague-Dawley rats (male:female, 1:1 in each experiment; age, 7-8 weeks; weight, 200-220 g) were purchased from the Third Military Medical University (Chongqing, China), and housed under controlled conditions: Food and water supplied ad libitum; a $12 \mathrm{~h}$ light/dark cycle; constant temperature $\left(22^{\circ} \mathrm{C}\right)$ and humidity (45-55\%). The rats were randomly assigned into four groups: i) Control group $(n=20)$, exposed to room air; ii) HALI group $(n=20)$, where rats were exposed to $5.0 \mathrm{l} / \mathrm{min}$ pure oxygen for $48 \mathrm{~h}$, performed in an air-tight plastic chamber to maintain the concentration of oxygen ( $>95 \%$ ), as previously described (30); iii) miR-21-5p + HALI group $(\mathrm{n}=20)$, where rats were sedated with 5\% isoflurane and AAV-6-miR-21-5p was endotracheally administered at an MOI of $10^{6}$ to the lung through an endotracheal tube inserted into the trachea, then 3 weeks later, the rats were exposed to pure oxygen to induce HALI; and iv) miR-21-5p control + HALI group $(n=20)$, where a control AAV-6 was endotracheally administrated to the lung through an endotracheal tube, then 3 weeks, the rats were exposed to pure oxygen in order to induce HALI. No rats showed any signs of adverse weight loss in the four groups, and therefore no rats were excluded from the study.

Sample collection, oxygenation index (OI) and respiratory index (RI) calculation. At 0, 24, 48 and $60 \mathrm{~h}$ after hyperoxia exposure, rats from the four groups were sedated with $5 \%$ isoflurane. Blood $(2 \mathrm{ml})$ was collected from the carotid artery and subjected to arterial blood gas analysis, and the OI and RI were calculated. The rats were euthanized by exsanguination, and the left lung was collected for the wet/dry weight analysis, then the rats were transcardially perfused with $4 \%$ paraformaldehyde prior to collection of the right lung for hematoxylin and eosin (H\&E) staining and pathological score calculation.

Detection of lung wet/dry weight ratio. As previously reported (30), after euthanasia of the rats, the lungs were surgically dissected away from the heart, trachea and main bronchi, then placed into a bottle, weighed, and dried to a constant weight in an oven at $70^{\circ} \mathrm{C}$ for $48 \mathrm{~h}$. The wet/dry weight ratio was calculated to assess lung edema and to quantify the lung water content. Lung water content was calculated as: Lung water content $=[($ wet weight-dry weight $) /$ wet weight $] \times 100 \%$.

Histological examination. As previously reported (30), the lungs collected for histological analyses were fixed with $4 \%$ paraformaldehyde at room temperature for $24 \mathrm{~h}$, followed by embedment in paraffin to dehydration, then sectioned (5 $\mu \mathrm{m}$ thickness). The sections were stained with hematoxylin and $0.5 \%$ eosin for 5 and $3 \mathrm{~min}$, respectively, in room temperature $\left(\sim 22^{\circ} \mathrm{C}\right)$. Tissue sections were observed under a light microscope. Lung injury was scored as previously described by Matute-Bello et al (31). The parameters used to analyze HALI severity were: i) Neutrophils in alveoli; ii) neutrophils in pulmonary interstitium; iii) transparent membrane; iv) areas filled with protein debris; and v) thickness of alveolar septum.

AEC II isolation and culture. The isolation of AEC II was performed based on a previously described method $(24,32)$. Following anesthesia of the rats, lungs were removed and blood and leukocytes were replaced with PBS. Lungs were minced and digested by $0.25 \%$ trypsin for $25 \mathrm{~min}$ at $37^{\circ} \mathrm{C}$. The effects of trypsin were neutralized with DMEM/F12 containing $10 \%$ FBS. The cell suspension was sequentially filtered through $70 \mu \mathrm{m}$ cell strainers and centrifuged at $110 \mathrm{x} \mathrm{g}$ at room temperature for $5 \mathrm{~min}$. The supernatant was then removed, and the cell pellets were resuspended in collagenase and incubated for $15 \mathrm{~min}$ at $37^{\circ} \mathrm{C}$. Collagenase activity was neutralized by the addition of the same medium containing FBS and the cells were centrifuged again at $110 \mathrm{x} \mathrm{g}$ at room temperature for $5 \mathrm{~min}$. Cell pellets were resuspended and cultured in flasks 

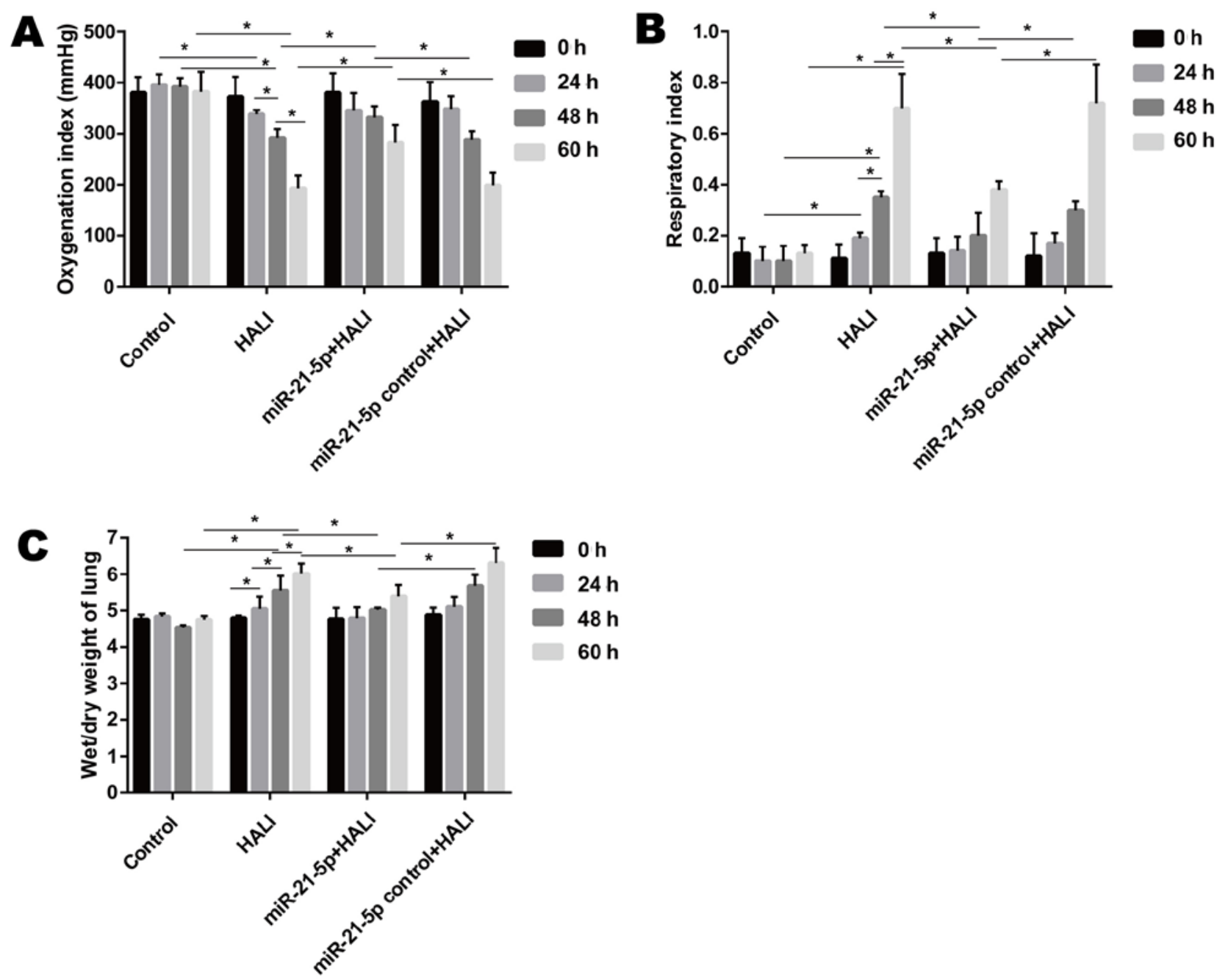

Figure 1. Administration of AAV-6-miR-21-5p in lung decreases HALI in rats. Rats were untreated (control), treated with hyperoxia (HALI), or administered with negative control or miR-21-5p-encoding AAV and then treated with hyperoxia. (A) The oxygenation index, (B) respiratory index and (C) wet/dry weight ratio of the lungs were measured in the four experimental groups. Data are expressed as mean \pm standard deviation ( $\mathrm{n}=6$ rats per group). $\mathrm{P}<0.05 \mathrm{with}$ comparisons shown by lines. AAV, adeno-associated virus; miR, microRNA; HALI, hyperoxic acute lung injury.

containing DMEM/F12 medium with $10 \% \mathrm{FBS}$ in a $37^{\circ} \mathrm{C}$, 95\% air humidity, and $5 \% \mathrm{CO}_{2}$ incubator.

AEC II cell identification by TEM. AEC II were identified by TEM as previously described (23). AEC II were incubated for $48 \mathrm{~h}$ and digested with $0.125 \%$ trypsin. The cell suspension was collected and centrifuged at $100 \mathrm{x}$ g for $10 \mathrm{~min}$ at $4^{\circ} \mathrm{C}$. The supernatant was removed and the cells were fixed with $4 \%$ glutaraldehyde at room temperature for $24 \mathrm{~h}$. The cell pellet was rinsed three times for $10 \mathrm{~min}$ at $4^{\circ} \mathrm{C}$ in PBS and fixed at $4^{\circ} \mathrm{C}$ for $30 \mathrm{~min}$ in $1 \%$ osmium tetroxide, then rinsed three times with PBS and observed by TEM.

miR-21-5p and PTEN mRNA expression level detection by $R T$ - $q P C R$. At $0,24,48$ and $60 \mathrm{~h}$ after isolation and culture, cells from each group were washed twice with PBS, extracted with $500 \mu 1$ TRIzol $^{\circledR}$ (Thermo Fished Scientific, Inc.) at room temperature for $5 \mathrm{~min}$, and centrifuged for $5 \mathrm{~min}$ $\left(15,000 \mathrm{x} \mathrm{g}, 4^{\circ} \mathrm{C}\right)$. The supernatant was collected, $0.1 \mathrm{ml}$ chloroform was added and mixed at room temperature for $5 \mathrm{~min}$, and the sample was centrifuged again for $15 \min \left(15,000 \mathrm{x} \mathrm{g}, 4^{\circ} \mathrm{C}\right)$. An equal volume of isopropanol was added to the supernatant at room temperature for $10 \mathrm{~min}$, then centrifuged for $10 \mathrm{~min}$ $\left(15,000 \times \mathrm{g}, 4^{\circ} \mathrm{C}\right)$. DEPC water was used to dissolve the RNA pellet. The absorbance of the RNA solution was measured at 260 and $280 \mathrm{~nm}\left(\mathrm{OD}_{260}\right.$ and $\left.\mathrm{OD}_{280}\right)$, and the concentration of the RNA was calculated. As previously described (24), the settings for reverse transcription were as follows: $37^{\circ} \mathrm{C}$ for $15 \mathrm{~min}$ and $85^{\circ} \mathrm{C}$ for $5 \mathrm{sec}$. The cDNA solution was stored at $-80^{\circ} \mathrm{C}$. The qPCR settings for miR-21-5p quantification were: $95^{\circ} \mathrm{C}$ for $5 \mathrm{~min} ; 39$ cycles of $95^{\circ} \mathrm{C}$ for $45 \mathrm{sec}, 60^{\circ} \mathrm{C}$ for $30 \mathrm{sec}, 72^{\circ} \mathrm{C}$ for $45 \mathrm{sec}$; and $72^{\circ} \mathrm{C}$ for $10 \mathrm{~min}$. The $\mathrm{Cq}$ values of miR-21-5p and U6 (as an internal reference control) were determined. The qPCR settings for PTEN quantification were: $94^{\circ} \mathrm{C}$ for $5 \mathrm{~min} ; 39$ cycles of $94^{\circ} \mathrm{C}$ for $45 \mathrm{sec}, 51^{\circ} \mathrm{C}$ for $30 \mathrm{sec}$, $72^{\circ} \mathrm{C}$ for $44 \mathrm{sec}$; and $72^{\circ} \mathrm{C}$ for $10 \mathrm{~min}$. The qPCR settings for $\beta$-actin quantification were: $94^{\circ} \mathrm{C}$ for $5 \mathrm{~min} ; 39$ cycles of $94^{\circ} \mathrm{C}$ for $45 \mathrm{sec}, 60^{\circ} \mathrm{C}$ for $30 \mathrm{sec}, 72^{\circ} \mathrm{C}$ for $44 \mathrm{sec}$; and $72^{\circ} \mathrm{C}$ for $10 \mathrm{~min}$. Relative expression levels were calculated using the $2^{-\Delta \Delta \mathrm{Cq}}$ method (33). The primer sequences were as follows: miR-21-5p, forward 5'-GTCAATAGCTTATCAGACTGA-3' and reverse 5'-GTTGGCTCTGGTGCAGGGTCCGAGGTA TTCGCA-3'; U6, forward 5'-GCTTCGGCAGCACATATA CTAAAAT-3' and reverse 5'-CGCTTCACGAATTTGCGT 


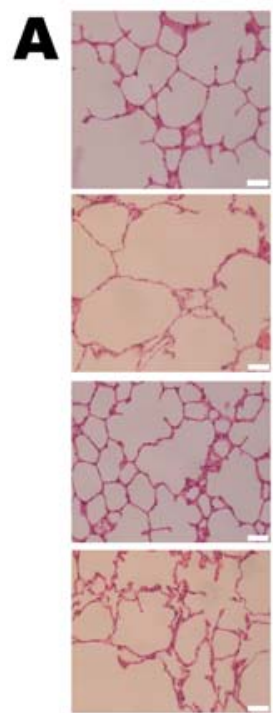

$\mathrm{Oh}$

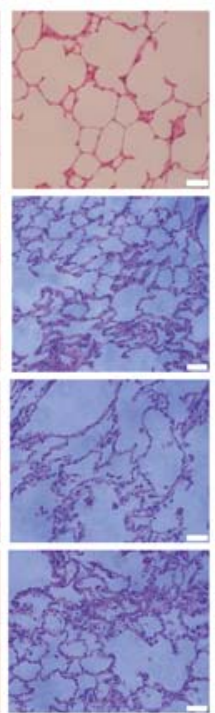

$24 \mathrm{~h}$

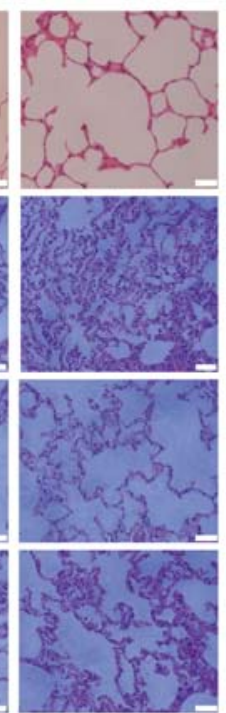

$48 \mathrm{~h}$

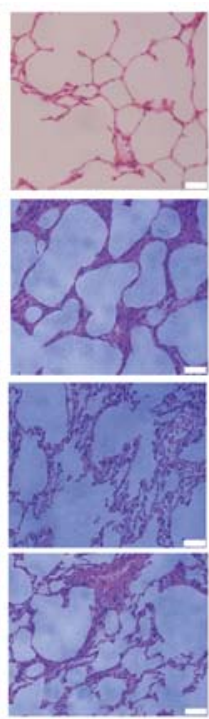

$60 \mathrm{~h}$

\section{Control}

HALI

miR-21-5p+HALI

miR-21-5p

control+HALI

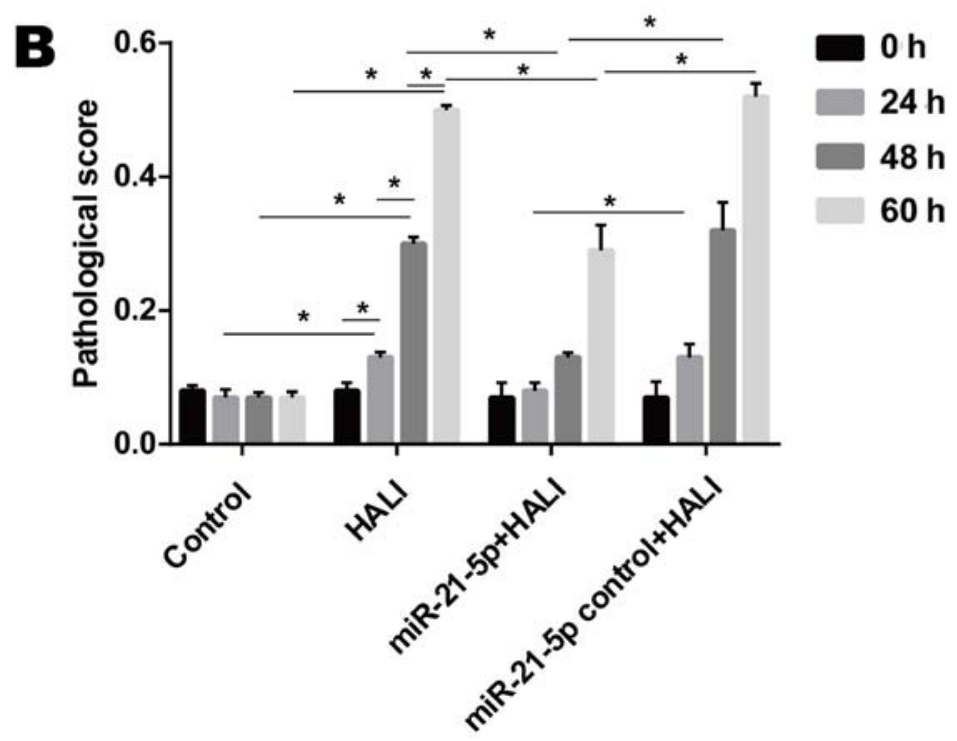

Figure 2. Administration of AAV-6-miR-21-5p decreases pathological changes in the lung tissues of HALI rats. (A) Pathological changes were examined by H\&E staining and light microscopy. Representative images are shown for each experimental group at the indicated times after HALI. Scale bar, $20 \mu \mathrm{m}$. (B) HALI-induced pathological changes were evaluated by calculating a pathological score. Data are expressed as the mean \pm standard deviation ( $=6$ rats per group). ${ }^{*}<0.05$ with comparisons shown by lines. AAV, adeno-associated virus; miR, microRNA; HALI, hyperoxic acute lung injury; H\&E, hematoxylin and eosin.

GTCAT-3'; PTEN, forward 5'-TTTGAAGACCATAACCCA CCAC-3' and reverse 5'-ATTACACCAGTTCGTCCCTTTC-3'; and $\beta$-actin, forward 5'-TTCCTCCGCAAGGATGACACGC-3' and reverse 5'-GTTGGCTCTGGTGCAGGGTCCGAGGTA TTCGCACCAGAGCCAACAAAAATAT-3'.

PTEN, pAKT and AKT protein expression detection via western blotting. Western blotting experiments were performed according to previously described standard procedures $(34,35)$. AEC II were lysed with $400 \mu 1$ lysis buffer (P0013, Beyotime Institute of Biotechnology) containing $100 \mathrm{mmol} / 1 \mathrm{PMSF}$ (ST506, Beyotime Institute of Biotechnology) for $30 \mathrm{~min}$. Proteins were obtained and stored at $-80^{\circ} \mathrm{C}$. The protein concentration was determined using the BCA method and separated via SDS-PAGE (10\% gel). Proteins were transferred to PVDF membrane and blocked with $5 \%$ skimmed milk at room temperature for $1 \mathrm{~h}$. The membranes were then incubated with rabbit anti-PTEN (1:2,000), rabbit anti-pan-AKT (1:500) and rabbit anti-pAKT (T308; 1:1,000) primary antibodies overnight at $4^{\circ} \mathrm{C}$, followed by goat anti-rabbit secondary antibody $(1: 5,000)$ at room temperature for $1 \mathrm{~h}$. Enhanced chemiluminescence was used to detect the results. The strip optical density values were analyzed using a gel image analysis software (Image-Pro Plus; version 6.0; Meyer Instruments, Inc.).

Apoptosis detection with flow cytometry. Flow cytometry with Annexin V-FITC/PI staining was used to evaluate early and late apoptosis of AEC II cells (17). Using a FACSCalibur flow cytometer, the apoptosis rates of AEC II cells were detected.

AEC II cells were isolated from the lungs of rats in each of the four groups. Excluding the $0 \mathrm{~h}$ time point groups, 
AEC II cells were seeded in plates and cultured from each time point. On the day of detection, cells were digested with $1 \mathrm{ml} 0.125 \%$ trypsin/EDTA for $2 \mathrm{~min}$. Digested cells were centrifuged and the supernatant was removed. Cell density was adjusted to $2 \times 10^{5}$ cells $/ \mathrm{ml}$, and $100 \mu \mathrm{l}$ cell suspensions were cultured for $24 \mathrm{~h}$. A cell suspension for analysis was then prepared at $0,24,48$ and $60 \mathrm{~h}$ after isolation and culture. The cells were collected via centrifugation (100 x g, $5 \mathrm{~min})$, then washed twice with PBS (100 x g, $5 \mathrm{~min}$ ), and $500 \mu \mathrm{l}$ binding buffer was added. A total of $5 \mu \mathrm{l}$ Annexin V-FITC and $5 \mu \mathrm{l}$ PI were added and mixed at room temperature in the dark for 5-15 min. Apoptosis was detected via flow cytometry $1 \mathrm{~h}$ later.

Statistical analysis. SPSS software (version 23.0; IBM, Corp.) was used for the statistical analysis. Data were expressed as the mean \pm standard deviation. One-way ANOVA and post hoc Dunnett's T3 test were performed in order to compare the differences among and between groups, respectively. $\mathrm{P}<0.05$ was considered to indicate a statistically significant difference.

\section{Results}

AAV-6-miR-21-5p administration in lung decreases HALI in rats. When rats were exposed to $>95 \%$ oxygen, the OI decreased significantly after hyperoxia exposure, while the RI and wet/dry weight ratio of the lung increased significantly from 24 to $60 \mathrm{~h}$ after hyperoxia exposure (Fig. 1). Endotracheally administered AAV-6-miR-21-5p to the lung reversed these changes induced by HALI, as evidenced by increased OI and decreased RI and wet/dry weight ratio, compared with that of the miR-21-5p control + HALI group (Fig. 1).

AAV-6-miR-21-5p administration in the lung decreases pathological changes in the lung tissue of HALI rats. The microscopic results of $\mathrm{H} \& \mathrm{E}$-stained lung tissue sections revealed that neutrophils were rare in the alveolar pulmonary interstitium in the group control (Fig. 2A). In the HALI and the miR-21-5p control + HALI group, neutrophils were occasionally observed and were gradually increased in alveolar pulmonary interstitium at $60 \mathrm{~h}$ after hyperoxia (Fig. 2A). In addition, protein fragments and occasional hyaline membrane were observed in the alveolar interstitium at 48 and $60 \mathrm{~h}$ after hyperoxia (Fig. 2A), which indicated that HALI rats possessed severe lung injury. In the miR-21-5p + HALI group, the frequency of neutrophil occurrence, protein fragments and hyaline membrane decreased compared with the HALI or miR-21-5p control + HALI groups (Fig. 2A). Endotracheally administered AAV-6-miR-21-5p to the lung significantly decreased pathological changes in the lung of HALI rats, as evidenced by the decreased pathological score (Fig. 2B).

HALI and AAV-6-miR-21-5p administration in the lung induces miR-21-5p upregulation. After $24 \mathrm{~h}$ culture, the AEC II cells revealed adherent, island-like and spindle-like growth. After $48 \mathrm{~h}$ culture, AEC II cells were polygonal and up to $95 \%$ adherent (Fig. 3A). The presence of osmiophilic lamellar corpuscles and microvilli, both of which are characteristic structures of AEC II, was confirmed by TEM (Fig. 3C). RT-qPCR results demonstrated that both HALI
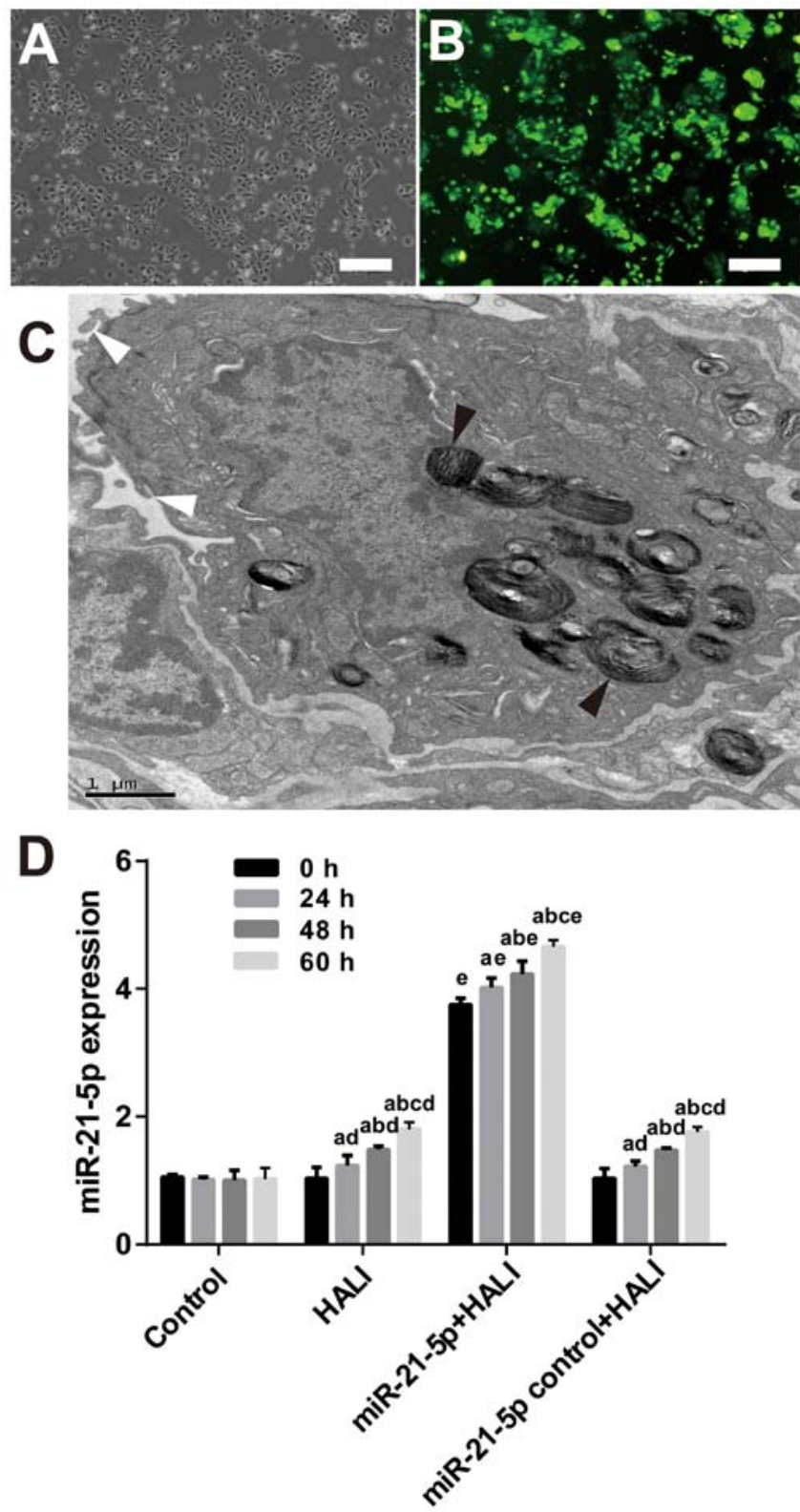

Figure 3. AAV-6-miR-21-5p-GFP administration in the lung induces miR-21-5p upregulation in AEC II cells. AAV-6 virus was dripped into the lungs of rats through tracheal intubation, and 3 weeks later, HALI was induced. AEC II were isolated from lungs at the indicated times after HALI and cultured for $24 \mathrm{~h}$. (A) Representative image of phase-contrast microscopy showing the cell morphology. Scale bar, $250 \mu \mathrm{m}$. (B) Representative image from fluorescence microscopy showing successful expression of the GFP tag in the AAV vector. Scale bar, $250 \mu \mathrm{m}$. (C) The isolated AEC II cells were confirmed by transmission electron microscopy. The black arrowheads indicate osmiophilic lamellar body and the white arrowheads indicate microvilli, both of which are characteristic structures of AEC II. Scale bar, $1 \mu \mathrm{m}$. (D) Reverse transcription-quantitative PCR analysis of the miR-21-5p levels in the AECII cells isolated from the experimental rats. Data are expressed as the mean \pm standard deviation ( $n=6$ rats per group). ${ }^{a} \mathrm{P}<0.05$ vs. $0 \mathrm{~h}$; ${ }^{\mathrm{b}} \mathrm{P}<0.05$ vs. $24 \mathrm{~h} ;{ }^{\mathrm{c}} \mathrm{P}<0.05$ vs. $48 \mathrm{~h} ;{ }^{\mathrm{d}} \mathrm{P}<0.05$ vs. the same time point in the control group; ${ }^{\mathrm{e}} \mathrm{P}<0.05$ vs. the same time point in the HALI group. AAV, adeno-associated virus; miR, microRNA; GFP, green fluorescent protein; AEC II, type II alveolar epithelial cells; HALI, hyperoxic acute lung injury.

and AAV-6-miR-21-5p administration in the lung induced miR-21-5p upregulation (Fig. 3D). However, AAV-6-miR-1-5p administration significantly increased miR-21-5p expression compared with the HALI group (Fig. 3D). 


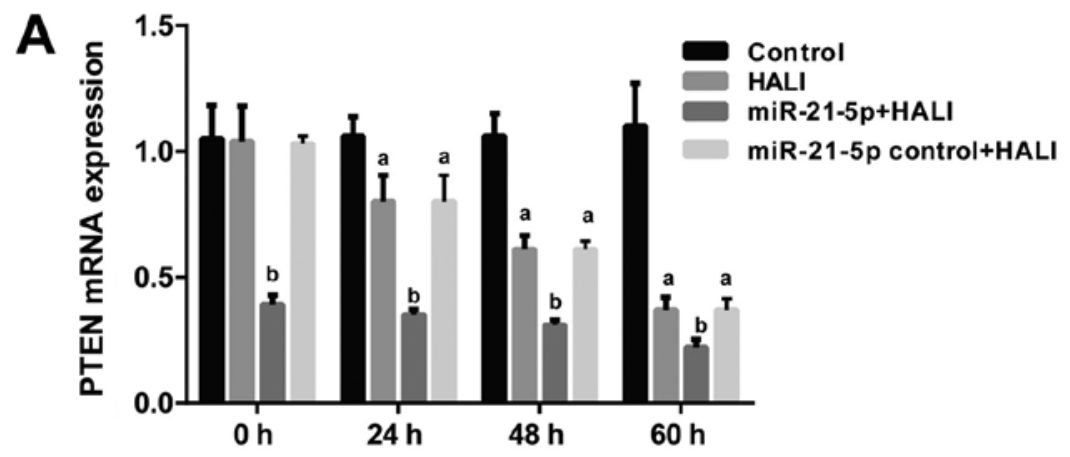

B
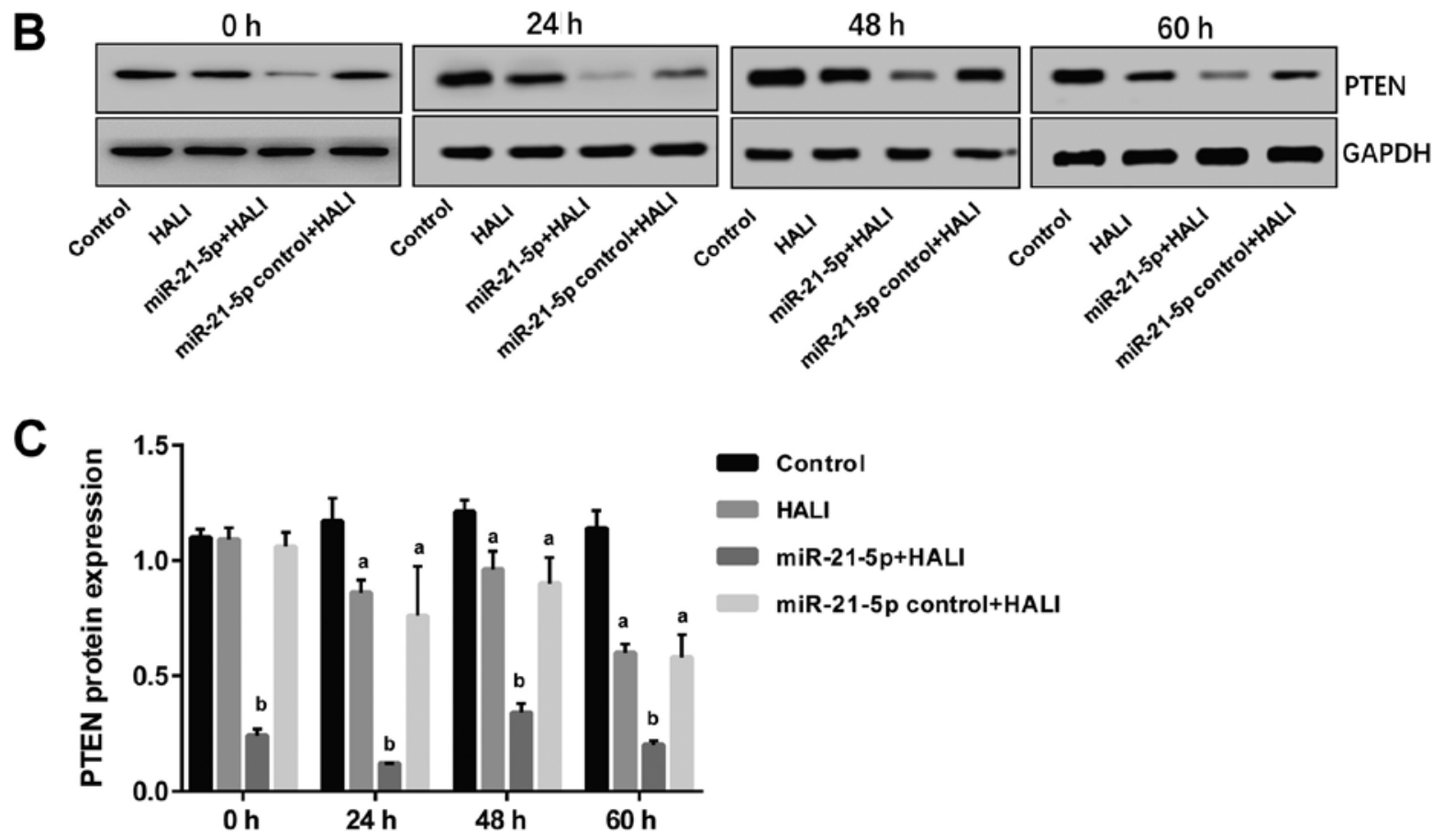

Figure 4. miR-21-5p overexpression decreases PTEN expression in AEC II from HALI lungs. PTEN expression was measured in the AEC II cells isolated from the lungs of experimental rats at the indicated times after HALI. (A) mRNA expression levels of PTEN. (B) Representative blots and (C) quantification of protein expression levels of PTEN. Data are expressed as the mean \pm standard deviation $\left(\mathrm{n}=6\right.$ rats per group). ${ }^{\mathrm{a}} \mathrm{P}<0.05 \mathrm{vs}$. the control group; ${ }^{\mathrm{b}} \mathrm{P}<0.05 \mathrm{vs}$. the HALI group. miR, microRNA; AEC II, type II alveolar epithelial cells; HALI, hyperoxic acute lung injury.

miR-21-5p overexpression decreases PTEN $m R N A$ and protein expression in AEC II cells isolated from the HALI lung. The expression levels of PTEN were detected via RT-qPCR and western blotting following isolation and culture of AEC II from HALI rats. The results revealed that both mRNA and protein PTEN expression were decreased in AEC II from the HALI rats (Fig. 4). However, in the miR-21-5p + HALI group, PTEN expression levels were significantly decreased compared with the HALI group, while the expression of PTEN in AEC II from rats receiving the negative control virus did not exhibit any change compared with the HALI rats (Fig. 4).

miR-21-5p overexpression increases AKT phosphorylation in $A E C$ II from the HALI lung. The protein expression levels of AKT and pAKT in AEC II from HALI rats were detected via western blotting following different culture times. pAKT/AKT ratios were calculated, and the results revealed that in the control group, pAKT/AKT demonstrated no difference between 0 and $24 \mathrm{~h}$; however, this ratio decreased significantly at 48 and $60 \mathrm{~h}$ compared with the 0 and $24 \mathrm{~h}$ time points $(\mathrm{P}<0.05$; Fig. 5). In HALI and miR-21-5p control + HALI groups, pAKT/AKT ratio was increased at $24 \mathrm{~h}$ of hyperoxia compared with their $0 \mathrm{~h}$ time points (Fig. 5). Of note, the miR-21-5p + HALI group exhibited the highest levels of p-AKT/AKT ratio among the four groups, which was significantly higher compared with that of group HALI and group miR-21-5p control + HALI (Fig. 5).

miR-21-5p overexpression decreases the apoptosis rate of $A E C$ II from the HALI lung. Flow cytometry (Fig. 6A) was employed in order to detect the apoptosis rate of AEC II cells isolated from the HALI lung that were cultured for different times. Control AEC II cells isolated from the normal lung exhibited low early and late apoptosis rates, 0.93-2.53 and $0.23-1.33 \%$ respectively (Fig. 6B and C). Cells isolated from the HALI lung exhibited gradually increased early and late apoptosis after 24,48 or $60 \mathrm{~h}$ culture (Fig. $6 \mathrm{~B}$ and C). AAV-miR-21-5p administrated to the lung decreased the early and late apoptosis rate of AEC II cells isolated from HALI 
A

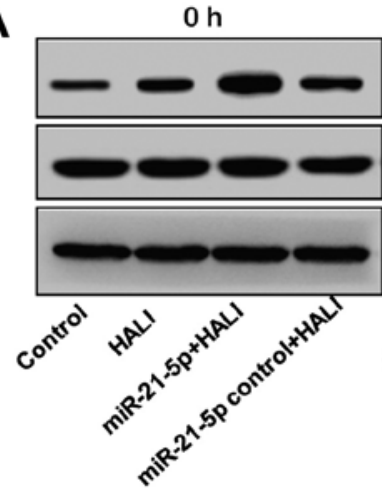

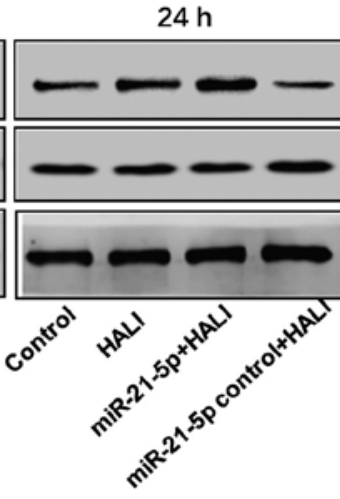
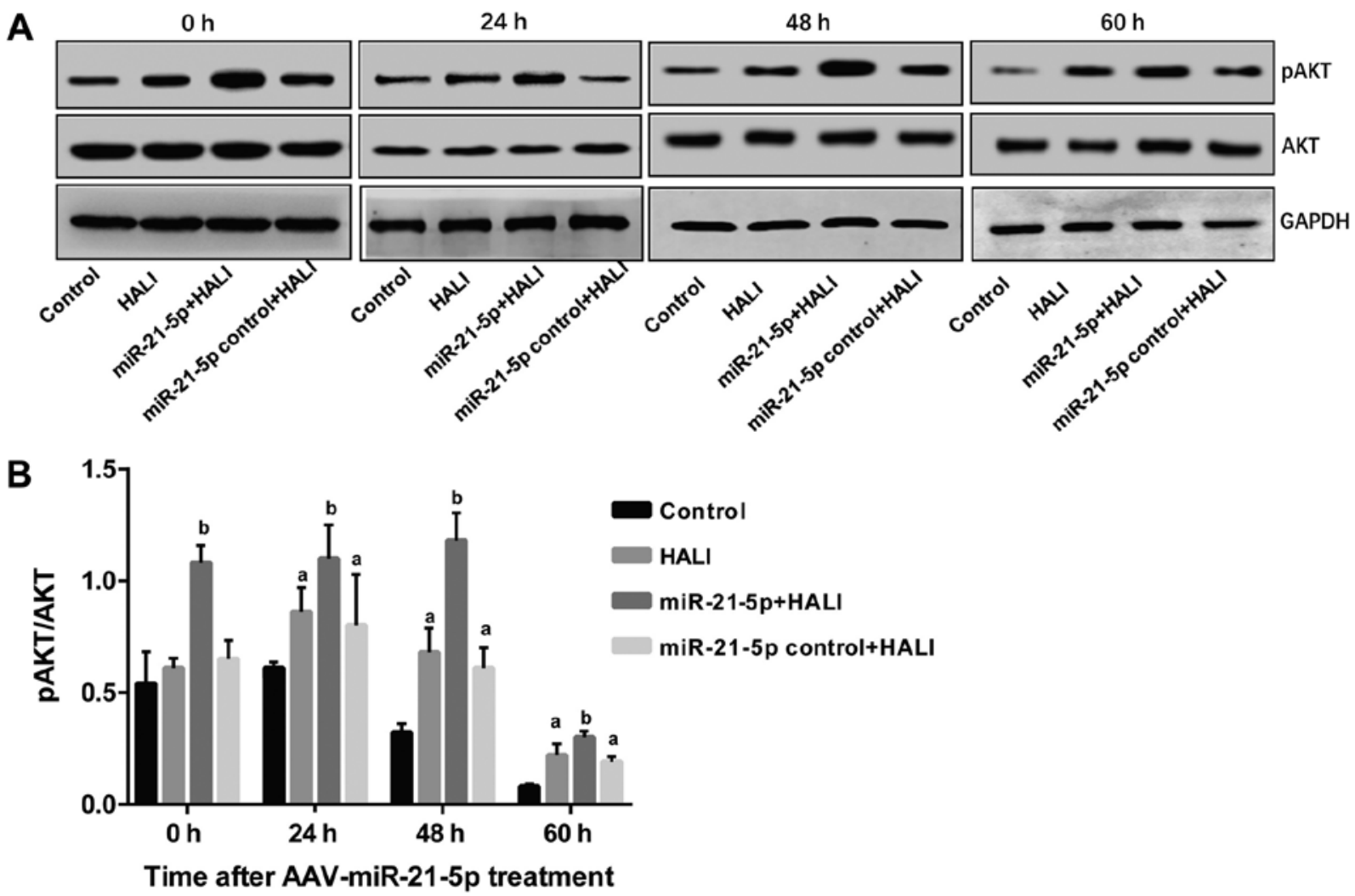

Figure 5. miR-21-5p overexpression enhances AKT phosphorylation in AEC II from HALI lungs. pAKT and total AKT protein expression levels were measured by western blotting in the AEC II cells isolated from the lungs of experimental rats at the indicated times after HALI. (A) Representative blot images. (B) Quantification of the pAKT/AKT ratio. Data are expressed as the mean \pm standard deviation ( $\mathrm{n}=6$ rats per group). ${ }^{\text {a }}<0.05$ vs. the same time point in the control group; ${ }^{b} \mathrm{P}<0.05$ vs. the same time point in the HALI group. miR, microRNA; AEC II, type II alveolar epithelial cells; HALI, hyperoxic acute lung injury; p, phosphorylated.

lung compared with that of the HALI group and the miR-21-5p control + HALI group (Fig. 6B and C).

\section{Discussion}

It has previously been reported that miR-21-5p expression decreased in AEC II cells when cells underwent $\mathrm{H}_{2} \mathrm{O}_{2}$ insult (23), but the specific underlying molecular mechanism is not yet fully understood. In the present study, rats were endotracheally administered AAV-6-miR-21-5p to the lung before a HALI model was established in these rats. miR-21-5p overexpression ameliorated HALI and decreased apoptosis of AEC II cells isolated from HALI rats. Molecular experiments demonstrated that miR-21-5p overexpression in the lung decreased PTEN mRNA and protein expression levels in AEC II cells isolated from HALI rats. In addition, the pAKT/AKT ratio increased following miR-21-5p intervention in lung of HALI rats. These results indicate that miR-21-5p targeted PTEN and decreased HALI via apoptosis-associated mechanisms.

The present study isolated the AEC II cells from the modeled rats and molecular changes in the isolated cells were investigated ex vivo; therefore, it can be concluded that the PTEN, AKT, pAKT expression and apoptosis results obtained from the HALI rats were due to the effects on the AEC II cells. The data from the present study demonstrated that miR-21-5p overexpression, as a result of administering AAV-6 carrying an miR-21-5p-expression vector, decreased the severity of HALI in vivo, and decreased the apoptosis rate of ACE II cells ex vivo. Further experiments revealed that PTEN mRNA and protein expression levels were negatively regulated by the expression of miR-21-5p. By using dual-luciferase reporter gene assay, it has previously been demonstrated that PTEN is one of the target genes of miR-21-5p $(24,36,37)$. Previous studies have revealed that miR-21 regulates cell proliferation and apoptosis in different disease models. For instance, in human hepatocellular carcinoma cells, downregulation of miR-21 increased the expression of PTEN, and decrease the proliferation, invasion and metastasis of hepatocarcinoma cells $(38,39)$. miR-21 overexpression inhibited the apoptosis of nasopharyngeal carcinoma cells, and dual-luciferase reporter assay revealed that miR-21-5p targeted the 3' untranslated region of the PTEN mRNA (36). miR-21-5p from mesenchymal stem cell-derived exosomes also inhibited hypoxia/reoxygenation-induced lung microvascular endothelial cell apoptosis in vitro, and decreased lung ischemia/reperfusion injury in vivo (40). Although no agonist/inhibitor of PTEN or AKT were used in the present study, our group has previously used the PTEN inhibitor Phen in an in vitro HALI model and found that PTEN inhibition partially offset $\mathrm{H}_{2} \mathrm{O}_{2}$-induced AECII apoptosis (24). In a previous study of $\mathrm{H}_{2} \mathrm{O}$-induced apoptosis in cardiac stem cells, it was found that the PTEN inhibitor Phen or the PI3K inhibitor LY294002 efficiently attenuated the antiapoptotic effect of miR-21/PTEN/AKT signaling (17). 
$\mathbf{A}$
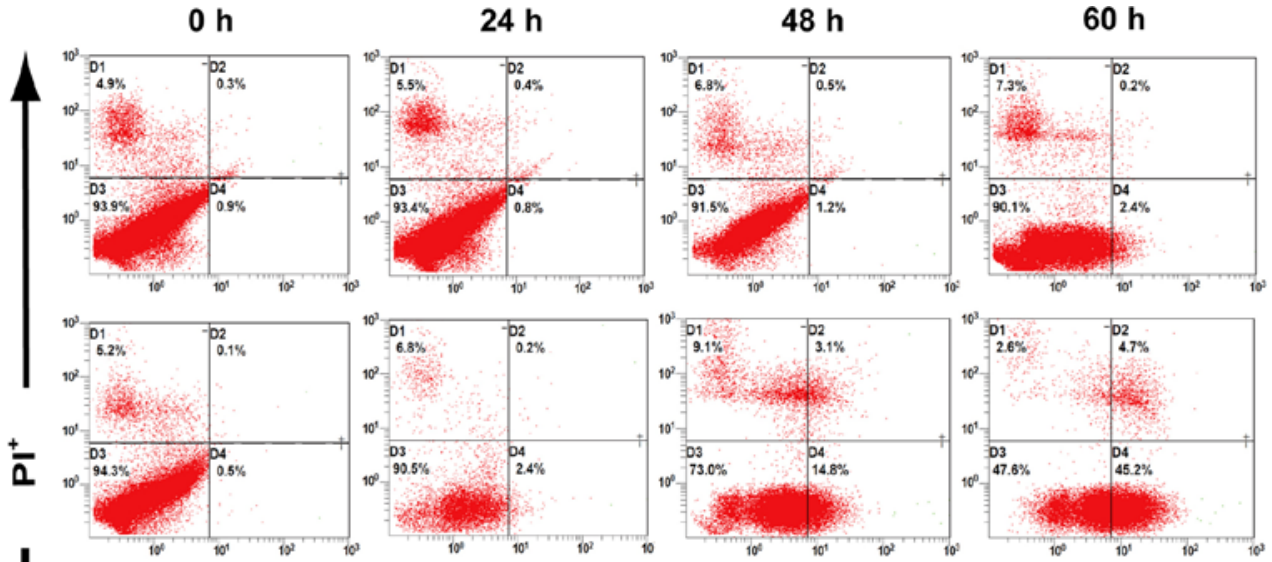

\section{Control}
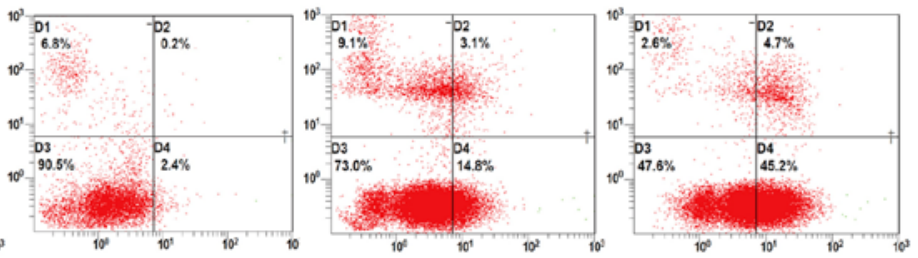

HALI
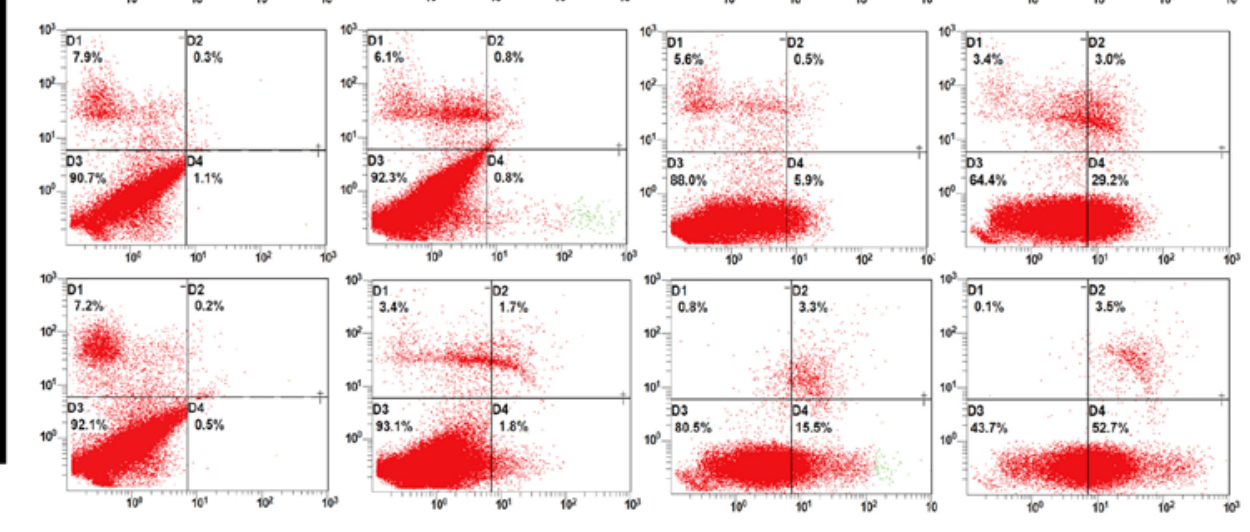

miR-21-5p+HALI

miR-21-5p

control+HALI

Annexin V-FITC+
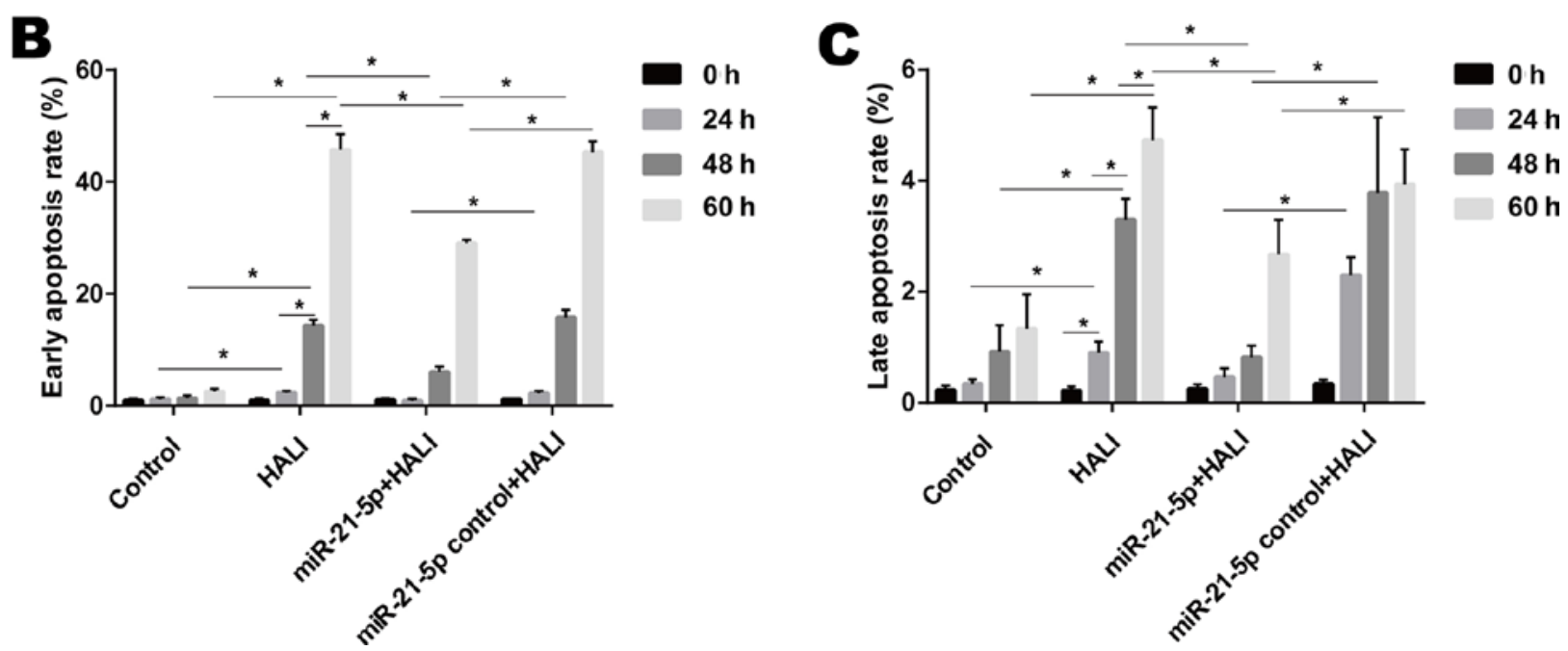

Figure 6. miR-21-5p overexpression inhibits apoptosis of AEC II isolated from HALI lungs. Apoptosis was measured by flow cytometry in the AEC II cells isolated from the lungs of experimental rats at the indicated times after HALI. (A) Representative plots. (B) Quantification of early apoptosis and (C) late apoptosis rates. Data are expressed as the mean \pm standard deviation ( $\mathrm{n}=6$ rats per group). ${ }^{*} \mathrm{P}<0.05$ with comparisons shown by lines.

A number of studies have reported that the PTEN/AKT axis is associated with apoptosis (41-43). In cancer research, PTEN is known to inhibit the growth of cancer cells and lead to apoptosis (44). HALI induces a pathological condition in lung tissues, and PTEN overexpression in HALI AEC II may accelerate cell apoptosis, although no study has reported that miR-21-5p decreases ACE II apoptosis through PTEN/AKT. miR-21-5p overexpression promotes non-small cell lung cancer cell growth and mobility through the PTEN-AKT axis (45). miR-21-5p overexpression also enhanced the invasion and sphere forming abilities of keratinocytes through
PTEN/AKT signaling (46). Finally, it was previously demonstrated that miR-21-5p decreased ACE II apoptosis through the PTEN/AKT pathway in vitro using an $\mathrm{H}_{2} \mathrm{O}_{2}$-induced HALI model (24). The results from the present study confirmed that miR-21-5p overexpression ameliorated HALI in vivo via PTEN/AKT-associated antiapoptotic pathways.

Although miRNA-21-associated therapies have not been applied to clinical use, it is believed that gene therapy is an effective strategy for ARDS/acute lung injury (ALI) treatment (47). In the present study, miR-21-5p was successfully administered to the lung through the trachea. In fact, cells in 
the lung, such as alveolar epithelial cells, can be specifically targeted through endotracheal intubation management (48), or through antibodies, pulmonary endothelial cell surface antigen and selective targeting intravenous injection (49). These data indicated the operability of miRNA-based therapy in ARDS/ALI. Although studies regarding the protective effects of miR-21-5p in pulmonary diseases are still in the laboratory research phase, it can be speculated that the elucidation of the antiapoptotic mechanism of miR-21-5p may bring opportunities for the application of miR-21-5p-associated therapies to the clinic.

\section{Acknowledgements}

Not applicable.

\section{Funding}

The present study was supported by the National Natural Science Foundation of China (grant no. 8156010205).

\section{Availability of data and materials}

The datasets analyzed/generated during the present study are available from the corresponding author upon reasonable request.

\section{Authors' contributions}

SQ, HW, HM and GL performed the experiments, wrote the article and prepared figures. MC conceived and designed the experiments, and provided the reagents, materials and analysis tools. All authors read and approved the final manuscript.

\section{Ethics approval and consent to participate}

All experimental procedures were performed according to the Guide for the Care and Use of Laboratory Animals. The protocol of the present study was approved by the Experimental Animal Care and Use Committee of Zunyi Medical University.

\section{Patient consent for publication}

Not applicable.

\section{Competing interests}

The authors declare that they have no competing interests.

\section{References}

1. Dos Santos CC: Hyperoxic acute lung injury and ventilatorinduced/associated lung injury: New insights into intracellular signaling pathways. Crit Care 11: 126, 2007.

2. Nyp MF, Mabry SM, Navarro A, Menden H,Perez RE, Sampath V and Ekekezie II: Lung epithelial-specific TRIP-1 overexpression maintains epithelial integrity during hyperoxia exposure. Physiol Rep 6: e13585, 2018.

3. Budinger GR, Mutlu GM, Urich D, Soberanes S, Buccellato LJ, Hawkins K, Chiarella SE, Radigan KA, Eisenbart J, Agrawal H, et al: Epithelial cell death is an important contributor to oxidant-mediated acute lung injury. Am J Respir Crit Care Med 183: 1043-1054, 2011
4. Lee HS and Kim CK: Cathepsin B is activated as an executive protease in fetal rat alveolar type II cells exposed to hyperoxia. Exp Mol Med 43: 223-229, 2011.

5. Kalluri R and Neilson EG: Epithelial-mesenchymal transition and its implications for fibrosis. J Clin Invest 112: 1776-1784 2003.

6. Barazzone C, Horowitz S, Donati YR, Rodriguez I and Piguet PF: Oxygen toxicity in mouse lung: Pathways to cell death. Am J Respir Cell Mol Biol 19: 573-581, 1998.

7. Lee HS and Kim CK: Effect of recombinant IL-10 on cultured fetal rat alveolar type II cells exposed to 65\%-hyperoxia. Respir Res 12: 68, 2011

8. Ma X, Xu D, Ai Y, Ming G and Zhao S: Fas inhibition attenuates lipopolysaccharide-induced apoptosis and cytokine release of rat type II alveolar epithelial cells. Mol Biol Rep 37: 3051-3056, 2010.

9. Kamp DW, Liu G, Cheresh P, Kim SJ, Mueller A,Lam AP, Trejo H, Williams D, Tulasiram S, Baker M, et al: Asbestos-induced alveolar epithelial cell apoptosis. The role of endoplasmic reticulum stress response. Am J Respir Cell Mol Biol 49: 892-901, 2013.

10. Liang X, Wei SQ, Lee SJ, Fung JK, Zhang M, Tanaka A, Choi AM and Jin Y: P62 sequestosome 1/light Chain 3b complex confers cytoprotection on lung epithelial cells after hyperoxia. Am J Respir Cell Mol Biol 48: 489-496, 2013.

11. Hengartner MO: The biochemistry of apoptosis. Nature 407: 770-776, 2000

12. Husari AW, Khayat A, Awdeh H, Hatoum H, Nasser M, Mroueh SM, Zaatari G, El-Sabban M and Dbaibo GS: Activated protein $\mathrm{C}$ attenuates acute lung injury and apoptosis in a hyperoxic animal model. Shock 33: 467-472, 2010.

13. Xu G, Zhang Y, Wei J, Jia W, Ge Z, Zhang Z and Liu X: MicroRNA-21 promotes hepatocellular carcinoma HepG2 cell proliferation through repression of mitogen-activated protein kinase-kinase 3. BMC Cancer 13: 469, 2013.

14. Teng Y, Radde BN, Litchfield LM, Ivanova MM, Prough RA, Clark BJ, Doll MA, Hein DW and Klinge CM: Dehydroepiandrosterone activation of G-protein-coupled estrogen receptor rapidly stimulates MicroRNA-21 transcription in human hepatocellular carcinoma cells. J Biol Chem 290: 15799-15811, 2015.

15. Dong S, Ma W, Hao B, Hu F, Yan L, Yan X, Wang Y, Chen Z and Wang Z: MicroRNA-21 promotes cardiac fibrosis and development of heart failure with preserved left ventricular ejection fraction by up-regulating Bcl-2. Int J Clin Exp Pathol 7: 565-574, 2014.

16. Richart A, Loyer X, Neri T, Howangyin K, Guérin CL, Ngkelo A, Bakker W, Zlatanova I, Rouanet M, Vilar J, et al: MicroRNA-21 coordinates human multipotent cardiovascular progenitors therapeutic potential. Stem Cells 32: 2908-2922, 2014.

17. Deng W, Wang Y, Long X, Zhao R, Wang Z, Liu Z, Cao S and Shi B: miR-21 reduces hydrogen peroxide-induced apoptosis in c-kit ${ }^{+}$cardiac stem cells in vitro through PTEN/PI3K/Akt signaling. Oxid Med Cell Longev 2016: 5389181, 2016.

18. Otsuka M, Kishikawa T, Yoshikawa T, Ohno M, Takata A, Shibata $C$ and Koike K: The role of microRNAs in hepatocarcinogenesis: Current knowledge and future prospects. J Gastroenterol 49: 173-184, 2014.

19. Yehya N, Yerrapureddy A, Tobias J and Margulies SS: MicroRNA modulate alveolar epithelial response to cyclic stretch. BMC Genomics 13: 154, 2012.

20. Li X, Mei ZJ, Wang YC, Chen J, Sun SX, Yau Y, Li Z and Xie C: Antagonism of miR-21 reverses radiation-induced EMT in alveolar epithelial cells via PI3K/Akt pathway. Int J Clin Exp Pathol 9: 1158-1167, 2016

21. Gomez IG, MacKenna DA, Johnson BG, Kaimal V, Roach AM, Ren S, Nakagawa N, Xin C, Newitt R, Pandya S, et al: Anti-microRNA-21 oligonucleotides prevent Alport nephropathy progression by stimulating metabolic pathways. J Clin Invest 125 : 141-156, 2015.

22. Dong L, Wang X, Tan J, Li H, Qian W, Chen J, Chen Q, Wang J, Xu W, Tao C and Wang S: Decreased expression of microRNA-21 correlates with the imbalance of Th17 and Treg cells in patients with rheumatoid arthritis. J Cell Mol Med 18: 2213-2224, 2014

23. Qin S, Chen M, Ji H, Liu GY, Mei H, Li K and Chen T: miR-21-5p regulates type II alveolar epithelial cell apoptosis in hyperoxic acute lung injury. Mol Med Rep 17: 5796-5804, 2018.

24. Qin S, Hui Y, Liu G, Mei $\mathrm{H}$ and Chen M: miR-21-5p targets PTEN and reduces $\mathrm{H}_{2} \mathrm{O}_{2}$-induced apoptosis in rat AECII cells. Int J Clin Exp Med 12: 5630-5637, 2019. 
25. Shi L, He Y, Bai B and Chen M: Effects of microRNA-21 inhibitor on apoptosis of type II alveolar epithelial cells in rats with hyperoxia-induced acute lung injury. Zhonghua Wei Zhong Bing Ji Jiu Yi Xue 29: 244-248, 2017 (In Chinese).

26. Tang $\mathrm{C}$, Gu Y, Wang H, Wu H, Wang Y, Meng Y, Han Z, Gu Y, Ma W, Jiang Z, et al: Targeting of microRNA-21-5p protects against seizure damage in a kainic acid-induced status epilepticus model via PTEN-mTOR. Epilepsy Res 144: 34-42, 2018.

27. Small EM, O'Rourke JR, Moresi V, Sutherland LB, McAnally J, Gerard RD, Richardson JA and Olson EN: Regulation of PI3-kinase/Akt signaling by muscle-enriched microRNA-486. Proc Natl Acad Sci USA 107: 4218-4223, 2010.

28. Poliseno L, Salmena L, Zhang J, Carver B, Haveman WJ and Pandolfi PP: A coding-independent function of gene and pseudogene mRNAs regulates tumour biology. Nature 465: 1033-1038, 2010.

29. Hao XJ, Xu CZ, Wang JT, Li XJ, Wang MM, Gu YH and Liang ZG: miR-21 promotes proliferation and inhibits apoptosis of hepatic stellate cells through targeting PTEN/PI3K/AKT pathway. J Recept Signal Transduct Res 38: 455-461, 2018.

30. Liu G, Mei H, Chen M, Qin S, Li K, Zhang W and Chen T: Protective effect of agmatine against hyperoxia-induced acute lung injury via regulating lncRNA gadd7. Biochem Biophys Res Commun 13: 68-74, 2019.

31. Matute-Bello G, Downey G, Moore BB, Groshong SD, Matthay MA, Slutsky AS and Kuebler WM; Acute Lung Injury in Animals Study Group: An official american thoracic society workshop report: Features and measurements of experimenta acute lung injury in animals. Am J Respir Cell Mol Biol 44: 725-738, 2011

32. Lin J, Tian J, Wang L, Wu W, Li H, Wang X, Zeng X and Zhang W: Apoptosis and surfactant protein-C expression inhibition induced by lipopolysaccharide in AEC II cell may associate with NF-кB pathway. J Toxicol Sci 42: 53-61, 2017.

33. Livak KJ and Schmittgen TD: Analysis of relative gene expression data using real-time quantitative PCR and the 2(-Delta Delta C(T)) method. Methods 25: 402-408, 2001.

34. Cao S, Xiao Z, Sun M and Li Y: D-serine in the midbrain periaqueductal gray contributes to morphine tolerance in rats. Mol Pain 12: pii: $1744806916646786,2016$.

35. Cao S, Li Q, Hou J, Li Z, Cao X, Liu X and Qin B: Intrathecal TRPM 8 blocking attenuates cold hyperalgesia via PKC and $\mathrm{NF}-\kappa \mathrm{B}$ signaling in the dorsal root ganglion of rats with neuropathic pain. J Pain Res 12: 1287-1296, 2019.

36. Ou H, Li Y and Kang M: Activation of miR-21 by STAT3 induces proliferation and suppresses apoptosis in nasopharyngeal carcinoma by targeting PTEN gene. PLoS One 9: e109929, 2014.

37. Fang L, Wang X, Sun Q, Papakonstantinou E, S'ng C, Tamm M, Stolz D and Roth M: IgE downregulates PTEN through microRNA-21-5p and stimulates airway smooth muscle cell remodeling. Int J Mol Sci 20: pii: E875, 2019.
38. Meng F, Henson R, Lang M, Wehbe H, Maheshwari S, Mendell JT, Jiang J, Schmittgen TD and Patel T: Involvement of human micro-RNA in growth and response to chemotherapy in human cholangiocarcinoma cell lines. Gastroenterology 130 2113-2129, 2006.

39. Meng F, Henson R, Wehbe-Janek H, Ghoshal K, Jacob ST and Patel T: MicroRNA-21 regulates expression of the PTEN tumor suppressor gene in human hepatocellular cancer. Gastroenterology 133: 647-658, 2007.

40. Li JW, Wei L, Han Z and Chen Z: Mesenchymal stromal cells-derived exosomes alleviate ischemia/reperfusion injury in mouse lung by transporting anti-apoptotic miR-21-5p. Eur J Pharmacol 852: 68-76, 2019.

41. Hu M, Zhu S, Xiong S, Xue X and Zhou X: MicroRNAs and the PTEN/PI3K/Akt pathway in gastric cancer (Review). Oncol Rep 41: 1439-1454, 2019.

42. Matsuda S, Nakagawa Y, Kitagishi Y, Nakanishi A and Murai T: Reactive oxygen species, superoxide dimutases, and PTEN-p53-AKT-MDM2 signaling loop network in mesenchymal stem/stromal cells regulation. Cells 7: pii: E36, 2018.

43. Gao X, Qin T, Mao J, Zhang J, Fan S, Lu Y, Sun Z, Zhang Q, Song B and Li L: PTENP1/miR-20a/PTEN axis contributes to breast cancer progression by regulating PTEN via PI3K/AKT pathway. J Exp Clin Cancer Res 38: 256, 2019.

44. Carnero A, Blanco-Aparicio C, Renner O, Link W and Leal JF: The PTEN/PI3K/AKT signalling pathway in cancer, therapeutic implications. Curr Cancer Drug Targets 8: 187-198, 2008.

45. Ren W, Hou J, Yang C, Wang H, Wu S, Wu Y, Zhao X and $\mathrm{Lu} \mathrm{C}$ : Extracellular vesicles secreted by hypoxia pre-challenged mesenchymal stem cells promote non-small cell lung cancer cell growth and mobility as well as macrophage $\mathrm{M} 2$ polarization via miR-21-5p delivery. J Exp Clin Cancer Res 38: 62, 2019.

46. Yan L, Cao R, Liu Y, Wang L, Pan B, Lv X, Jiao H, Zhuang Q, Sun $\mathrm{X}$ and Xiao R: miR-21-5p links epithelial-mesenchymal transition phenotype with stem-like cell signatures via AKT signaling in keloid keratinocytes. Sci Rep 6: 28281, 2016.

47. Devaney J, Contreras M and Laffey JG: Clinical review: Gene-based therapies for ALI/ARDS: Where are we now? Crit Care 15: 224, 2011

48. MacLoughlin RJ, Higgins BD, Laffey JG and O'Brien T: Optimized aerosol delivery to a mechanically ventilated rodent. J Aerosol Med Pulm Drug Deliv 22: 323-332, 2009.

49. Suen CM, Mei SH, Kugathasan L and Stewart DJ: Targeted delivery of genes to endothelial cells and cell- and gene-based therapy in pulmonary vascular diseases. Compr Physiol 3: $1749-1779,2013$

This work is licensed under a Creative Commons Attribution-NonCommercial-NoDerivatives 4.0 International (CC BY-NC-ND 4.0) License. 